\title{
An Empirical Study on Import, Export and Economic Growth in Albania
}

\section{Ph.D Güngör Turan}

Department of Economics,, Epoka University, Tirana, Albania

Email: gturan@epoka.edu.al

\section{Bernard Karamanaj}

MSc Student at Banking and Finance, Epoka University, Tirana, Albania

Doi:10.5901/ajis.2014.v3n3p428

Email: bkaramanaj@gmail.com

\section{Abstract}

Imports and Exports have an important role in the Economic Growth of a country. This paper discusses the relationship between export, import and Gross Domestic Product (GDP) in Albania by using annual data for the period between 1984 and 2012. Different empirical researches and macro econometric models indicates that there is an equilibrium relationship between exports, imports and GDP in the long term. The main goal is to find if imports and exports affect the GDP growth in Albania? The relationship between this variables is shown by using Econometric Views statistical package and the source of data used is World Bank.

Keywords: Import, Export, GDP, Econometric Views, World Bank, Albania

\section{Introduction}

The relationship between import, export (also known as international trade) and economic growth has been a very popular subject showing interest of policy makers and academics. The reason is simple. The main goal of almost every nation is to increase GDP and improve the quality of life for their citizens. In Albania, which is a developing country international trade (import, export) is an important factor that effects GDP or economic growth

Albania is a small economy located in Balkan. After fall of communist regime in 1990 Albania became a small open economy. The GDP of Albania increased year by year starting from 1991 till 2008 excluding year 1997. After 2008 GDP of Albania had slightly movements, decreasing and increasing.

Figure 1. GDP of Albania (1991-2012)

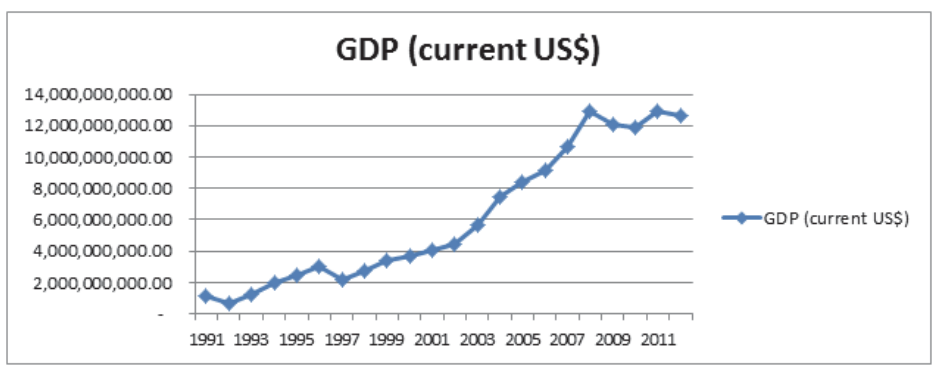

Source: World Bank

In general, the international trade is considered an important factor for the economic growth especially for a small open economy like Albanian economy. By having a quick look on the trade performance over the last decade and the relationship of trade performance with the county's overall development we can highlight two specific contributions of trade.

First, through import trade peoples in Albania fulfilled their basic needs. In 1990 Albania changed from a closed economy to an open economy. So people were mostly focused on imported goods and services because Albania could 
not fulfill their needs.

Second, although far from desired levels, trade has played and is playing a significant role in the re-allocation of productive resources. Structural changes in the economy, expressed in the increased share of services and their diversity, increasing the weight of the construction, transport, etc. as well as the introduction of new technologies in some sectors of the economy are the expression of this role. Important institutional changes of recent years such as Albania 's membership in the World Trade Organization ( WTO ) and the signing of a series of bilateral agreements of free trade with region countries, accompanied these with a significant reduction in trade barriers .

The number of studies done to measure economic growth through exports and imports in Albania is very limited. This paper is an attempt to make an empirical examination of the hypothesis export-led growth. It also examines long-run impact of exports, imports on GDP growth in case of Albania.

\section{Literature Review}

Different studies and researches were done by academics and policy makers for economic growth, import and export. A variety of studies shows different results about the relationship of this three variables. Export led hypothesis is a widely known hypothesis and accepted by different academics (Feder 1982; Kruege 1990).

Atrkar Roshan Sedigheh (2008) made a study about export expansion and economic growth in Iran after the revolution period. The results of this study confirms the relationship between these variables in Iran after the revolution period.

A study done by Ahmet Ugur (2008), shows the relationship between imports and economic growth in Turkey.

Velnampy. T, Achchuthan (2013); Based on the overall study, in the Sri Lankan context, the export and import have the significant positive relationship, and also, both export and import have the significant impact on the economic growth. Further, the export and import have been associated by 98 percent, which denotes that, there is a strong positive association between export and import.

Another study done by Murat Çetinkaya and Savas Erdogan (2010) tested the relationship of two figures, importexport by using VAR Analysis. According to the study it was determined that there was causality relationship between these variables, the variable import influenced GDP, and GDP influenced the variable export. Between export and import, two way Causality relationships released mutually. In the same way, the results of causality overlap with variance decomposition test.

Mehdi Taghavi, Masoumeh Goudarzi, Elham Masoudi, Hadi gashti (2012) studied the Iran economy from 19622011. VAR Analysis was applied between the variables of annual economic growth, import, and export. When regarding to these results, it is implied that the export increases as the country grows and the import indicates a decrease economic growth. When regarding to the data used in the study, they indicate a difference proportionally, it is seen that the increases or decreases in the import, export, and GDP always occur in the same period. This case indicates that the relationships between three variables are very strict.

Barbara Pistoresi and Alberto Rinaldi (2011), the nexus between trade and economic growth in Italy has been widely debated by historiography. The outcome suggests that three variables, GDP, import, export commove in the long run but the direction of causality varies across time.

However, there are also other studies that do not support the relationship between these variables. There is no causal relation between exports and economic growth, namely exports and economic growth are both the result of the development process and technological change ( Yaghmaian, 1994; Dritsakis, 2005).

Kogid, Mulok, Ching, Lily, Ghazali and Loganathan (2011) analyzed the relationship between the economic growth and the import in Malaysia from 1970 to 2007. Results show that there is no co integration exists between economic growth and import, but there exists bilateral causality between economic growth and import. Results also show that import could indirectly contribute to economic growth, and economic growth could also directly contribute to import. These findings may be vital for future economic growth policy.

Ali F. Darrat (1987) made a study about export-led hypothesis of Ronald Findlay (1984) and Anne Kruege (1985); This hypothesis states that higher exports accelerate the economic growth process. The empirical results reported by Ali F. Darrat (1987) shows that the economic growth of Hong Kong, Korea, Singapore and Taiwan are not affected by exports. Based on the Granger causality test, no causal effect were shown from exports to economic growth in any of the four countries.

Francisco (2000) investigated the Granger-causality between exports, imports, and economic growth in Portugal over the period 1865 - 1998. Findings revealed that, more interestingly, there is no kind of significant causality between import- export growth. Further, researcher concluded that the growth of output for the Portuguese economy during that 
period revealed a shape associated with a small dual economy in which the intra-industry transactions were very limited.

As stated above there are different arguments about the relationship and effect of Export and Import on Economic growth. The relationship of these three variables differs from country to country. Also the arguments are controversial. Based on these arguments we can generate different hypothesis about the relationship of these variables.

\section{Data and Methodology}

This section includes the empirical analysis of the relation of Gross Domestic Product with Import and Export . To inspect the relation between GDP with Import and Export a time series regression model is conducted once with no lag and later with one lag included. Data included in the regression are the annual changes in percentage of GDP, Import and Export.

\section{The Relation of Gross Domestic Product with Import and Export}

The two model conducted are:

$$
\begin{aligned}
& G D P_{t}=C_{t}+\beta_{0} E X_{t}+\beta_{1} I M P_{t}+u_{t} \\
& G D P_{t}=C_{t}+\beta_{0} E X_{t}+\beta_{1} I M P_{t}+\beta_{2} E X_{t-1}+\beta_{3} I M P_{t-1}+u_{t}
\end{aligned}
$$

Where:

- $\mathrm{GDP}_{\mathrm{t}}$ in both model is the dependent variable.

- $\mathrm{GDP}_{\mathrm{t}}$ represent Gross Domestic Product annual changes in percentage at time t.

- $E X_{t}$ and $E X_{t-1}$ represent Export annual changes in percentage respectively at time $t$ and $t-1$.

- $\quad \mathrm{IMP}_{\mathrm{t}}$ and IMP $\mathrm{I}_{\mathrm{t}-1}$ represent Import annual changes in percentage respectively at time $t$ and $\mathrm{t}-1$.

- $\mathrm{C}_{\mathrm{t}}$ represent the intercept which $\mathrm{GDP}_{\mathrm{t}}$ equal if all the independent variables equals zero.

- $\beta_{0}, \beta_{1}, \beta_{2}$ and $\beta_{3}$ are the slopes of their respective variable.

- $\mathrm{u}_{\mathrm{t}}$ represents the estimated error.

The Eview program the results for the no lag model are shown in table 1 and for the one lag model in table 2. Accordingly, the estimated models are.

$$
\begin{aligned}
& G D P_{t}=-0.012+0.521 E X_{t}-0.106 I M P_{t}+0.222 E X_{t-1}+0.03 I M P_{t-1} \\
& G D P_{t}=0.035+0.589 E X_{t}-0.277 I M P_{t}
\end{aligned}
$$

Table 1

Dependent Variable: GDP

Method: Least Squares

\begin{tabular}{|c|c|c|c|c|}
\hline Variable & Coefficient & Std. Error & t-Statistic & Prob. \\
\hline $\begin{array}{l}\text { EX } \\
\text { IMP } \\
C\end{array}$ & $\begin{array}{c}0.588980 \\
-0.227415 \\
0.034920\end{array}$ & $\begin{array}{l}0.079780 \\
0.124190 \\
0.031340\end{array}$ & $\begin{array}{c}7.382567 \\
-1.831186 \\
1.114231\end{array}$ & $\begin{array}{l}0.0000 \\
0.0790 \\
0.2758\end{array}$ \\
\hline $\begin{array}{l}\text { R-squared } \\
\text { Adjusted R-squared } \\
\text { S.E. of regression } \\
\text { Sum squared resid } \\
\text { Log likelihood } \\
\text { F-statistic } \\
\text { Prob(F-statistic) }\end{array}$ & $\begin{array}{l}0.691013 \\
0.666294 \\
0.142715 \\
0.509192 \\
16.36960 \\
27.95481 \\
0.000000\end{array}$ & $\begin{array}{l}\text { Mean dependent var } \\
\text { S.D. dependent var } \\
\text { Akaike info criterion } \\
\text { Schwarz criterion } \\
\text { Hannan-Quinn criter. } \\
\text { Durbin-Watson stat }\end{array}$ & & $\begin{array}{l}0.098206 \\
0.247052 \\
-0.954971 \\
-0.812235 \\
-0.911335 \\
2.034327\end{array}$ \\
\hline
\end{tabular}

Date: 06/16/14 Time: 22:13

Sample: 19852012

Included observations: 28

According to the results EX is statistically significant at significance level $0.05 \%$ ( $p$-value $<0.05$ ) in predicting the model. Also an annual increase by 1 percent in exports will increase GDP by 0.58 percent. Moreover, the imports data are not 
statistically significant in predicting the model at the significance level at $0.05 \%$ however they significant at significance level $1 \%$ (p-value $=0.07)$. The results indicate that 1 percent annual increase in imports will decrease GDP by 0.23 percent. According to the p-value of F-statistics which equal 0.00, it can be concluded that Exports and Imports data jointly are statistically significant in predicting the model

\title{
Table 2
}

\author{
Dependent Variable: GDP \\ Method: Least Squares \\ Date: 06/16/14 Time: 22:18 \\ Sample (adjusted): 19862012 \\ Included observations: 27 after adjustments
}

\begin{tabular}{|c|c|c|c|c|}
\hline Variable & Coefficient & Std. Error & t-Statistic & Prob. \\
\hline $\begin{array}{c}\text { EX } \\
\text { IMP } \\
\text { EX(-1) } \\
\text { IMP(-1) } \\
C\end{array}$ & $\begin{array}{c}0.520971 \\
-0.106079 \\
0.222313 \\
0.030464 \\
-0.011810\end{array}$ & $\begin{array}{l}0.088267 \\
0.121758 \\
0.070233 \\
0.136255 \\
0.033497\end{array}$ & $\begin{array}{c}5.902214 \\
-0.871231 \\
3.165354 \\
0.223579 \\
-0.352565\end{array}$ & $\begin{array}{l}0.0000 \\
0.3930 \\
0.0045 \\
0.8251 \\
0.7278\end{array}$ \\
\hline $\begin{array}{l}\text { R-squared } \\
\text { Adjusted R-squared } \\
\text { S.E. of regression } \\
\text { Sum squared resid } \\
\text { Log likelihood } \\
\text { F-statistic } \\
\text { Prob(F-statistic) }\end{array}$ & $\begin{array}{l}0.795319 \\
0.758104 \\
0.123592 \\
0.336050 \\
20.90416 \\
21.37109 \\
0.000000\end{array}$ & \multicolumn{2}{|l|}{$\begin{array}{l}\text { Mean dependent var } \\
\text { S.D. dependent var } \\
\text { Akaike info criterion } \\
\text { Schwarz criterion } \\
\text { Hannan-Quinn criter. } \\
\text { Durbin-Watson stat }\end{array}$} & $\begin{array}{r}0.101052 \\
0.251291 \\
-1.178086 \\
-0.938116 \\
-1.106730 \\
2.022456\end{array}$ \\
\hline
\end{tabular}

According to the results 1 percent increase in export will increase both the current GDP and GDP of the next coming year by respectively 0.52 and 0.22 percent. While an increase in imports will decrease the current GDP by 0.10 percent and increase the GDP of the next coming year by 0.03 percent. Moreover, only the current and previous annual $\%$ change of exports are separately statistically significant in predicting the model. All other variables are separately statistically insignificant in predicting the model. However, all the variables are jointly statistically significant in predicting the model.

\section{Unit Root Tests}

Furthermore, the Augmented Dickey-Fuller and Phillips-Perron Test are conducted in order to check the series have a unit root. Table 5-9 show the test statistics respectively for GDP, EX and IMP. Accordingly, all the p-value of the test, are less than 0.05 indicating that the null hypothesis of the ADF Test, which is that the tested series has a unit root, can be rejected. Thus, it can be concluded that GDP, Export and Import series are non-stationary.

According to table 6-8, which show the result of PP test for respectively GDP, EX and IMP indicate that the series do not have a unit root and are non-stationary because the p-value is less than 0.05 and thus, the null hypothesis which predict a unit root for each test series can be rejected. 
Table 3: ADF Test GDP (level)

Null Hypothesis: GDP has a unit root

Exogenous: Constant

Lag Length: 0 (Automatic - based on SIC, maxlag=0)

\begin{tabular}{|c|c|c|c|}
\hline & & t-Statistic & Prob.* \\
\hline \multicolumn{2}{|c|}{ Augmented Dickey-Fuller test statistic } & -3.737283 & 0.0092 \\
\hline Test critical values: & $\begin{array}{c}1 \% \text { level } \\
5 \% \text { level } \\
10 \% \text { level }\end{array}$ & $\begin{array}{l}-3.699871 \\
-2.976263 \\
-2.627420\end{array}$ & \\
\hline
\end{tabular}

*MacKinnon (1996) one-sided p-values.

Table 4: ADF Test EXPORTS (level)

Null Hypothesis: EX has a unit root

Exogenous: Constant

Lag Length: 0 (Automatic - based on SIC, maxlag=0)

\begin{tabular}{cccc}
\hline \hline & t-Statistic & Prob.* \\
& & \\
\hline \hline Augmented Dickey-Fuller test statistic & -4.374356 & 0.0020 \\
\hline Test critical values: & $1 \%$ level & -3.699871 & \\
& $5 \%$ level & -2.976263 & \\
& $10 \%$ level & -2.627420 & \\
& & & \\
\hline \hline
\end{tabular}

*MacKinnon (1996) one-sided p-values.

Table 5: ADF Test IMPORTS (level)

Null Hypothesis: IMP has a unit root

Exogenous: Constant

Lag Length: 0 (Automatic - based on SIC, maxlag=0)

\begin{tabular}{|c|c|c|c|}
\hline & & t-Statistic & Prob.* \\
\hline \multicolumn{2}{|c|}{ Augmented Dickey-Fuller test statistic } & -5.746192 & 0.0001 \\
\hline Test critical values: & $\begin{array}{c}1 \% \text { level } \\
5 \% \text { level } \\
10 \% \text { level }\end{array}$ & $\begin{array}{l}-3.699871 \\
-2.976263 \\
-2.627420\end{array}$ & \\
\hline
\end{tabular}

*MacKinnon (1996) one-sided p-values. 
Table 6: PP Test GDP (level)

Null Hypothesis: GDP has a unit root

Exogenous: Constant

Bandwidth: 5 (Newey-West automatic) using Bartlett kernel

\begin{tabular}{cccc}
\hline \hline & & Adj. t-Stat & Prob.* \\
\hline \hline Phillips-Perron test statistic & & -3.524272 & 0.0150 \\
\hline Test critical values: & $1 \%$ level & -3.699871 & \\
& $5 \%$ level & -2.976263 & \\
& $10 \%$ level & -2.627420 & \\
& & & \\
& & & \\
& & & \\
\end{tabular}

*MacKinnon (1996) one-sided p-values.

Table 7: PP Test EXPORTS (level)

Null Hypothesis: EX has a unit root

Exogenous: Constant

Bandwidth: 8 (Newey-West automatic) using Bartlett kernel

\begin{tabular}{|c|c|c|c|}
\hline & & Adj. t-Stat & Prob.* \\
\hline \multicolumn{2}{|c|}{ Phillips-Perron test statistic } & -4.322073 & 0.0022 \\
\hline \multirow[t]{3}{*}{ Test critical values: } & 1\% level & -3.699871 & \\
\hline & $5 \%$ level & -2.976263 & \\
\hline & $10 \%$ level & -2.627420 & \\
\hline
\end{tabular}

*MacKinnon (1996) one-sided p-values.

Table 8: PP Test IMPORTS (level)

Null Hypothesis: IMP has a unit root

Exogenous: Constant

Bandwidth: 5 (Newey-West automatic) using Bartlett kernel

\begin{tabular}{cccc}
\hline \hline & & Adj. t-Stat & Prob.* \\
& & & \\
\hline \hline \multicolumn{2}{c}{ Phillips-Perron test statistic } & -5.894665 & 0.0000 \\
\hline Test critical values: & $1 \%$ level & -3.699871 & \\
& $5 \%$ level & -2.976263 & \\
& $10 \%$ level & -2.627420 & \\
& & & \\
\hline \hline
\end{tabular}

*MacKinnon (1996) one-sided p-values.

\section{Conclusion}

Based on the study done, the import and export have an significant relationship with GDP. Exports have a significant impact on the economic growth. The study shows that an annual increase by 1 percent in Exports will increase GDP by 0.58 percent. Regarding the import, it has a negative impact on economic growth. The results indicate that 1 percent annual increase in Imports will decrease GDP by 0.23 percent. According to the $\mathrm{p}$-value of F-statistics which equal 0.00 , it can be concluded that Exports and Imports data jointly are statistically significant in predicting the model. 
According to the results 1 percent increase in export will increase both the current GDP and GDP of the next coming year by respectively 0.52 and 0.22 percent. While an increase in imports will decrease the current GDP by 0.10 percent and increase the GDP of the next coming year by 0.03 percent.

\section{References}

A.I.Rashid, 1995. Trade, Growth and Liberalization: the Indian experience, 1977-1989. Journal of Developing Areas, Volume 29, pp. 355-370.

Arshia Amiri, Ulf-G Gerdtham, 2011. Relationship between exports, imports, and economic growth in France: evidence from cointegration analysis and Granger causality with using geostatistical models. Shiraz, Shiraz University Press.

Bank, W., 2014. World Bank. [Online] Available at: http://www.worldbank.org/[Accessed 13 April 2014].

CHIEN-HUI LEE, BWO-NUNG HUANG, 2002. The relationship between exports and economic growth in East Asian countries: A multivariate threshold autoregressive approach. JOURNAL OF ECONOMIC DEVELOPMENT , 27(2), pp. 45-68.

D.Rodrik, 1996. Understanding Economic Policy Reforms. Journal of Economic Literature, Volume 34, pp. 9-41.

D.Salvatore, T.Hatcher, 1991. Inward and Outward Oriented Trade Strategies. Journal of Developing Studies, Volume 27, pp. 7-25.

Darrat, A. F., 1986. TRADE AND DEVELOPMENT: THE ASIAN EXPERIENCE. In: Louisiana: Louisiana Technical University Press, pp. 695-699.

Dilawar Khan, Azra, Maryum Umar, Nasreen Zaman, Ejaz Ahmad, Yusra Shoukat, 2012. Exports, Imports and Economic Growth Nexus: Time Series Evidence from Pakistan. Work Applied Sciences Journal, 18(4), pp. 538-542.

G.K.Nidugala, 2000. Exports and Economic Growth in India: An Empirical Investigation. Indian Economic Journal, Volume 47, pp. 67-78.

Laszlo Konya, Jai Pal Singh, 2006. Exports, Imports and Economic Growth in India. Melbourne, La Trobe University Press.

Mehdi Taghavi, Masoumeh Goudarzi, Elham Masoudi, Hadi Parhizi Gashti, 2012. Study on the Impact of Export and Import on Economic Growth in Iran. Journal of Basic and Applied Scientific Research, Volume 2, pp. 12787-12794.

Robert Z. Lawrence, David E. Weinstein, 1999. TRADE AND GROWTH: IMPORT-LED OR EXPORT-LED? EVIDENCE FROM JAPAN AND KOREA. Massachusetts, Cambridge University Press.

T.Velnampy, S.Achchuthan, 2013. Export, Import and Economic Growth: Evidence from Sri Lanka. Journal of Economics and Sustainable Development, 4(9), pp. 147-155.

Uğur, A., 2008. Import and Economic Growth in Turkey: Evidence from Multivariate VAR Analysis. EAST-WEST Journal of ECONOMICS AND BUSINESS, 11(1-2), pp. 54-75.

Vika, I., 2006. Measuring Import and Export Functions in Albania, Tirana: Banka e Shqiperise.

\section{Appendix}

\section{ADF Test GDP (level)}

Null Hypothesis: GDP has a unit root

Exogenous: Constant

Lag Length: 0 (Automatic - based on SIC, maxlag=0)

\begin{tabular}{cccc}
\hline \hline & & t-Statistic & Prob.* \\
& & \\
\hline \hline Augmented Dickey-Fuller test statistic & -3.737283 & 0.0092 \\
\hline Test critical values: & 1\% level & -3.699871 & \\
& 5\% level & -2.976263 & \\
& 10\% level & -2.627420 & \\
& & & \\
&
\end{tabular}

*MacKinnon (1996) one-sided p-values.

Augmented Dickey-Fuller Test Equation

Dependent Variable: D(GDP)

Method: Least Squares

Date: 06/16/14 Time: 22:08

Sample (adjusted): 19862012

Included observations: 27 after adjustments

\begin{tabular}{ccccc}
\hline \hline Variable & Coefficient & Std. Error & t-Statistic & Prob. \\
\hline \hline GDP(-1) & -0.719733 & 0.192582 & -3.737283 & 0.0010 \\
& $\sim 434 \sim$ & &
\end{tabular}




$\begin{array}{lllll}\text { C } & 0.072259 & 0.051320 & 1.407989 & 0.1714\end{array}$

\begin{tabular}{llll}
\hline \hline R-squared & 0.358436 & Mean dependent var & -0.001682 \\
Adjusted R-squared & 0.332774 & S.D. dependent var & 0.301230 \\
S.E. of regression & 0.246056 & Akaike info criterion & 0.104675 \\
Sum squared resid & 1.513593 & Schwarz criterion & 0.200662 \\
Log likelihood & 0.586893 & Hannan-Quinn criter. & 0.133217 \\
F-statistic & 13.96728 & Durbin-Watson stat & 1.785551 \\
Prob(F-statistic) & 0.000970 & &
\end{tabular}

\section{ADF Test Exports (level)}

Null Hypothesis: EX has a unit root

Exogenous: Constant

Lag Length: 0 (Automatic - based on SIC, maxlag=0)

\begin{tabular}{cccc}
\hline \hline & & t-Statistic & Prob.* \\
& & \\
\hline \hline & & & \\
\hline \multicolumn{2}{c}{ Augmented Dickey-Fuller test statistic } & -4.374356 & 0.0020 \\
\hline & 1\% level & -3.699871 & \\
& 5\% level & -2.976263 & \\
& 10\% level & -2.627420 & \\
& & \\
\hline \hline
\end{tabular}

*MacKinnon (1996) one-sided p-values.

Augmented Dickey-Fuller Test Equation

Dependent Variable: D(EX)

Method: Least Squares

Date: 06/16/14 Time: 22:10

Sample (adjusted): 19862012

Included observations: 27 after adjustments

\begin{tabular}{lclll}
\hline \hline \multicolumn{1}{c}{ Variable } & Coefficient & Std. Error & t-Statistic & Prob. \\
& & & \\
\hline \multicolumn{1}{c}{ EX(-1) } & -0.870203 & 0.198933 & -4.374356 & 0.0002 \\
& 0.143191 & 0.081004 & 1.767704 & 0.0893 \\
& & & & \\
\hline \hline R-squared & 0.433556 & Mean dependent var & -0.001801 \\
Adjusted R-squared & 0.410898 & S.D. dependent var & 0.500381 \\
S.E. of regression & 0.384057 & Akaike info criterion & 0.995137 \\
Sum squared resid & 3.687501 & Schwarz criterion & 1.091125 \\
Log likelihood & -11.43436 & Hannan-Quinn criter. & 1.023680 \\
F-statistic & 19.13499 & Durbin-Watson stat & 1.897335 \\
Prob(F-statistic) & 0.000189 & & \\
& & & \\
\hline \hline
\end{tabular}




\section{ADF Test Imports (level)}

Null Hypothesis: IMP has a unit root

Exogenous: Constant

Lag Length: 0 (Automatic - based on SIC, maxlag=0)

\begin{tabular}{|c|c|c|c|}
\hline & & t-Statistic & Prob.* \\
\hline \multicolumn{2}{|c|}{ Augmented Dickey-Fuller test statistic } & -5.746192 & 0.0001 \\
\hline Test critical values: & $\begin{array}{c}1 \% \text { level } \\
5 \% \text { level } \\
10 \% \text { level }\end{array}$ & $\begin{array}{l}-3.699871 \\
-2.976263 \\
-2.627420\end{array}$ & \\
\hline
\end{tabular}

*MacKinnon (1996) one-sided p-values.

Augmented Dickey-Fuller Test Equation

Dependent Variable: D(IMP)

Method: Least Squares

Date: 06/16/14 Time: 22:10

Sample (adjusted): 19862012

Included observations: 27 after adjustments

\begin{tabular}{lcllc}
\hline \hline \multicolumn{1}{c}{ Variable } & Coefficient & Std. Error & t-Statistic & Prob. \\
& & & & \\
\hline \multicolumn{1}{c}{ IMP(-1) } & -1.157045 & 0.201359 & -5.746192 & 0.0000 \\
& 0.156594 & 0.054908 & 2.851914 & 0.0086 \\
& & & & \\
\hline \hline R-squared & 0.569105 & Mean dependent var & -0.004633 \\
Adjusted R-squared & 0.551869 & S.D. dependent var & 0.366357 \\
S.E. of regression & 0.245249 & Akaike info criterion & 0.098103 \\
Sum squared resid & 1.503678 & Schwarz criterion & 0.194091 \\
Log likelihood & 0.675613 & Hannan-Quinn criter. & 0.126645 \\
F-statistic & 33.01872 & Durbin-Watson stat & 2.020477 \\
Prob(F-statistic) & 0.000005 & & \\
& & & \\
\hline
\end{tabular}

\section{PP Test GDP (level)}

Null Hypothesis: GDP has a unit root

Exogenous: Constant

Bandwidth: 5 (Newey-West automatic) using Bartlett kernel

\begin{tabular}{cccc}
\hline \hline & & Adj. t-Stat & Prob. $^{*}$ \\
& & & \\
\hline \hline \multicolumn{2}{c}{ Phillips-Perron test statistic } & -3.524272 & 0.0150 \\
\hline Test critical values: & $1 \%$ level & -3.699871 & \\
& $5 \%$ level & -2.976263 & \\
& $10 \%$ level & -2.627420 & \\
& & & \\
\hline \hline
\end{tabular}

*MacKinnon (1996) one-sided p-values.

\begin{tabular}{ll}
\hline \hline Residual variance (no correction) & 0.056059 \\
HAC corrected variance (Bartlett kernel) & 0.031685
\end{tabular}

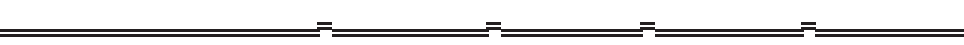


Phillips-Perron Test Equation

Dependent Variable: D(GDP)

Method: Least Squares

Date: 06/16/14 Time: 22:09

Sample (adjusted): 19862012

Included observations: 27 after adjustments

\begin{tabular}{lcccc}
\hline \hline \multicolumn{1}{c}{ Variable } & Coefficient & Std. Error & t-Statistic & Prob. \\
& & & & \\
\hline \multicolumn{1}{c}{ GDP(-1) } & -0.719733 & 0.192582 & -3.737283 & 0.0010 \\
& 0.072259 & 0.051320 & 1.407989 & 0.1714 \\
& & & & \\
\hline \hline R-squared & 0.358436 & & -0.001682 \\
Adjusted R-squared & 0.332774 & & 0.301230 \\
S.E. of regression & 0.246056 & & 0.104675 \\
Sum squared resid & 1.513593 & & 0.200662 \\
Log likelihood & 0.586893 & & 0.133217 \\
F-statistic & 13.96728 & & 1.785551 \\
Prob(F-statistic) & 0.000970 & & \\
& & & \\
\hline \hline
\end{tabular}

\section{PP Test Exports (level)}

Null Hypothesis: EX has a unit root

Exogenous: Constant

Bandwidth: 8 (Newey-West automatic) using Bartlett kernel

\begin{tabular}{cccc}
\hline \hline & & Adj. t-Stat & Prob. $^{*}$ \\
& & & \\
\hline \hline Phillips-Perron test statistic & -4.322073 & 0.0022 \\
\hline Test critical values: & $1 \%$ level & -3.699871 & \\
& $5 \%$ level & -2.976263 & \\
& $10 \%$ level & -2.627420 & \\
& & & \\
\hline \hline
\end{tabular}

*MacKinnon (1996) one-sided p-values.

Residual variance (no correction)

0.136574

HAC corrected variance (Bartlett kernel)

0.077872

Phillips-Perron Test Equation

Dependent Variable: D(EX)

Method: Least Squares

Date: 06/16/14 Time: 22:11

Sample (adjusted): 19862012

Included observations: 27 after adjustments

\begin{tabular}{ccccc}
\hline \hline Variable & Coefficient & Std. Error & t-Statistic & Prob. \\
& & & & \\
\hline \hline EX(-1) & -0.870203 & 0.198933 & -4.374356 & 0.0002 \\
C & 0.143191 & 0.081004 & 1.767704 & 0.0893 \\
& & & & \\
\hline \hline R-squared & 0.433556 & Mean dependent var & -0.001801 \\
Adjusted R-squared & 0.410898 & S.D. dependent var & 0.500381
\end{tabular}




$\begin{array}{lcll}\text { S.E. of regression } & 0.384057 & \text { Akaike info criterion } & 0.995137 \\ \text { Sum squared resid } & 3.687501 & \text { Schwarz criterion } & 1.091125 \\ \text { Log likelihood } & -11.43436 & \text { Hannan-Quinn criter. } & 1.023680 \\ \text { F-statistic } & 19.13499 & \text { Durbin-Watson stat } & 1.897335 \\ \text { Prob(F-statistic) } & 0.000189 & \end{array}$

\section{PP Test Imports (level)}

Null Hypothesis: IMP has a unit root

Exogenous: Constant

Bandwidth: 5 (Newey-West automatic) using Bartlett kernel

\begin{tabular}{cccc}
\hline \hline & & Adj. t-Stat & Prob. $^{*}$ \\
& & & \\
\hline \hline Phillips-Perron test statistic & -5.894665 & 0.0000 \\
\hline Test critical values: & 1\% level & -3.699871 & \\
& 5\% level & -2.976263 & \\
& 10\% level & -2.627420 & \\
& & & \\
\hline \hline
\end{tabular}

*MacKinnon (1996) one-sided p-values.

Residual variance (no correction)

0.055692

HAC corrected variance (Bartlett kernel)

0.040893

Phillips-Perron Test Equation

Dependent Variable: D(IMP)

Method: Least Squares

Date: 06/16/14 Time: 22:11

Sample (adjusted): 19862012

Included observations: 27 after adjustments

\begin{tabular}{lllll}
\hline \hline \multicolumn{1}{c}{ Variable } & Coefficient & Std. Error & t-Statistic & Prob. \\
& & & & \\
\hline \multicolumn{1}{c}{ IMP(-1) } & -1.157045 & 0.201359 & -5.746192 & 0.0000 \\
& 0.156594 & 0.054908 & 2.851914 & 0.0086 \\
& & & & \\
\hline \hline R-squared & 0.569105 & Mean dependent var & -0.004633 \\
Adjusted R-squared & 0.551869 & S.D. dependent var & 0.366357 \\
S.E. of regression & 0.245249 & Akaike info criterion & 0.098103 \\
Sum squared resid & 1.503678 & Schwarz criterion & 0.194091 \\
Log likelihood & 0.675613 & Hannan-Quinn criter. & 0.126645 \\
F-statistic & 33.01872 & Durbin-Watson stat & 2.020477 \\
& & & \\
\hline \hline
\end{tabular}

